\title{
Turizm Eğitimi Alan Öğrencilerin Turizm Sektörü Algıları: Karabük Üniversitesi Öğrencileri Üzerine bir Araştırma
}

\author{
Nuray Türkera*, Mehmet Uçarb, Muzaffer Ali Ateşc \\ aKarabük Üniversitesi, Safranbolu Turizm Fakültesi, Karabük \\ b, cKarabük Üniversitesi, Sosyal Bilimler Enstitüsü, Karabük
}

\section{$\ddot{O} z$}

Turizm sektörünün gelecek çalışanları olan turizm bölümü öğrencilerinin turizm sektörüne yönelik algilarının belirlenmesi sektörün sorunlarının, işgörenlerin sektörden uzaklaşma sebeplerini tespit edilmesi ve eğitimli işgörenlerin sektöre çekilmesi açısından önem taşımaktadır. Zira turizm eğitimi alan öğrencilerin önemli bir kısmı sektörün çalışma koşullarının ağır olması nedeniyle başka sektörlere kaymakta ve turizm sektöründen uzaklaşmaktadır. Bu noktadan hareketle öğrencilerin sektöre yönelik algılarının belirlenmesi öğrencileri sektörden uzaklaştıran hususların ortaya konulması açısından önem taşımaktadır. Bu çalışmada, Karabük Üniversitesi turizm bölümünde eğitim gören öğrencilerin turizme yönelik algılarl; çalışma koşulları, kişi-turizm uyumu, sosyal statü-terfi, yönetici ve iş arkadaşları, ücret ve ek ödemeler, motivasyon ve özel hayat boyutlarna göre değerlendirilmiştir. Anket tekniği kullanilarak 393 örneklemden elde edilen veriler parametrik olmayan Mann-Whitney $U$ Testi ve Kruskal-Wallis $H$ testleri ile analiz edilmiştir. Yapılan analizler öğrencilerin; sektörü çalışma koşulları açından olumsuz algıladıkların göstermektedir. Lisans ve önlisans turizm öğrencilerinin sektör algiları arasında anlamlı farklılık bulunmuştur.

Anahtar Kelimeler: Turizm algısı, turizm öğrencileri, meslek, Karabük.

\section{Perceptions of Tourism Students towards Tourism Industry: A study on Karabuk University Students}

\begin{abstract}
Determining the perceptions of university level tourism students towards tourism industry is a critical issue for identifying the problems of the industry, finding out the reasons that cause employees departing the industry, and attracting educated personnel into the sector. Because a significant number of educated students move away from the sector due to the hard working conditions and shift to other sectors. From this point of view determining the perceptions of tourism students towards the tourism industry is significant in order to find out the reasons that detract students from the sector. In this study, perceptions of Karabük University students studying tourism were examined from the perspectives of working conditions, employee-tourism harmony, social status-promotion, managers and colleagues, wages and additional payments, motivation and private life. Using the survey technique data obtained from the sample of 393 respondents were analyzed by non-parametric tests such as Mann-Whitney U Testi and Kruskal-Wallis H tests. Analysis showed that students have negative perceptions towards the working conditions of the industry. There are also significant
\end{abstract}

\footnotetext{
*Yazışma adresi: E-mail: nturker@karabuk.edu.tr
} 
differences between the perceptions of undergraduate and graduate degree students towards the industry.

Keywords: Tourism perceptions, tourism students, career, Karabük.

\section{GİRiş}

1980'li yıllardan başlayarak devlet desteği ve teşviklerin de yardımıyla önemli bir gelişme kaydeden Türk turizm endüstrisi, ülkenin kalkınmasında ve istihdamın artmasında itici bir güç olmuştur. Bu süreçte fiziksel nitelikleri yüksek turizm tesisleri ve altyapı yatırımları dikkate değer bir şekilde artmış ve 2000'li yıllara gelindiğinde sektör tüm dünyada turizm gelirleri ve turist sayısı bakımından ilk on ülke arasında yer almaya başlamıştır. Bununla birlikte sektörün gelişmesinden başlayarak önemli bir problem olan nitelikli işgücü sorunu hala önemini korumaktadır. İstihdam yaratıcı önemli bir sektör olan turizm endüstrisinde var olan düşük ücret, mevsimlik istihdam, yorucu ve uzun çalışma saatleri, yönetsel sorunlar v.b. olumsuz koşullar nedeniyle turizm eğitimi alan nitelikli personelin önemli bir kısmı sektörde çalışmak istememekte ve sektörden uzaklaşmaktadır. Sektörün hizmet odaklı yapısı ve turistlerin temel ihtiyaçlarından ziyade psikolojik ihtiyaçlarının tatmin edilmesi zorunluluğu, nitelikli işgücü ihtiyacını açık bir biçimde ortaya koymaktadır (Hacıoğlu, 2010).

Sektörün nitelikli eleman ihtiyacını karşılamak amacıyla hem ortaöğretim hem de yüksek öğretim düzeyinde eğitim veren pek çok okul açılmıştır. 2014 yılı itibarıyle bünyesinde turizm ve otelcilik programı bulunan meslek yüksekokulu sayısı 161 olup bu programların 2014 yılı toplam yeni kayıt öğrenci kontenjanı 17.380'dir. 2012-2013 öğretim yılı itibariyle ön lisans düzeyinde turizm eğitimi alan öğrenci sayısı 41.755'dir (Boylu, ve Arslan, 2014). Lisans düzeyinde eğitim veren okul sayısı ise 2014 yılı itibarıle 59 olup bu okullara yerleşen toplam öğrenci sayısı 8.882'dir. Bununla birlikte 2012-2013 EğitimÖğretim yılında turizm lisans eğitimi alan 28.040 öğrenciden sadece 3.295'i mezun olmuştur (Orhan, 2015). Aymankuy ve Aymankuy (2013) sektöre işgücü yetiştiren çok sayıda okul olmasına karşın turizm sektöründe en önemli sorunlardan birinin turizm eğitimi almış, nitelikli iş gücü eksikliği olduğunu ifade etmektedir.

Turizm mesleği ile ilgili olumsuz algılamalar öğrencilerin meslek seçimi tercihlerini etkilemektedir. Meslek seçimi, bireyin ilgi, yetenek, değer, beklenti ve kişilik özelliklerine uygun olarak seçildiğinde kişinin ruh sağlığını mesleki ve özel hayatını olumlu yönde etkilemekte ve bireyin hayat kalitesi ve standardına olumlu yönde katkı sağlamaktadır (Savickas, 1990). Bir meslekle ilgili özelliklerin ilgili programlarda okuyan öğrenciler tarafından nasıl algılandığının belirlenmesi, o mesleğin toplumda nasıl algılandığını ve olması gerektiği şekilde anlaşılıp anlaşılmadığını göstermektedir (Halıcı ve Delil, 2003:22). Bu bağlamda turizm eğitimi alan öğrencilerin turizmle ilgili algılarını 
belirlemek gelecekte bu kişilerin eğitim aldıkları alanda kariyerlerine devam edip etmeyeceklerini ortaya koymak açısından önem taşımaktadır.

Sektörün zor çalışma koşulları turizm eğitimi alan öğrencilerin sektöre karşı olumsuz tutum geliştirmelerine neden olmakta, turizm eğitimi alan pek çok işgören sektörde aradığını bulamamakta, sektörde kendisi ve kariyeri için bir gelecek görmemekte ve sektörde çalışmaktan kaçınmaktadır. Araştırmalar (Aksu ve Köksal, 2005; Birdir, 2002; Unur, Duman ve Tepeci, 2004), turizm eğitimi alan öğrencilerin sektöre karşı tutumlarının çoğunlukla olumsuz olduğunu, lisans düzeyinde turizm eğitimi alan öğrencilerin önemli bir kısmının turizm sektöründe çalışmadıklarını, turizm sektöründe istihdam edilen personelin önemli bir kısmının turizm eğitimi almayan işgörenlerden oluştuğunu göstermektedir. Nitekim Altman ve Brothers (1995), turizm eğitimi veren okullardan mezun olan öğrencilerin \% 30,6'sının 5 yıl içerisinde sektörü terk ettiklerini belirtirken, Pavesic ve Brymer (1990) turizm mezunlarının 1/5'inin mezuniyetlerinin ilk yılında, 1/3'ünün ise ilk 5 yıl içerisinde sektörü terk ettiklerini ortaya koymaktadır.

Hacıŏlu'na (1985) göre üniversite düzeyinde turizm eğitimi almış kişilerin yalnızca \% 6'sı turizm sektöründe çalışmaktadır. Ağaoğlu (1991), turizm sektöründe istihdam edilen personelin \% 22,3'ünün turizm eğitimi aldığını ifade etmektedir. Keza Milli Eğitim Bakanlığı tarafından 1999-2000 eğitim-öğretim yılında yapılan bir araştırma da turizm sektöründe çalışanların \%74,8'inin örgün turizm eğitimi almadıkları göstermektedir (Duman, Tepeci ve Unur, 2006).

Kuşluvan ve Kuşluvan (2003) lisans düzeyinde turizm eğitimi alan öğrencilerin 1/3'ünün sektörde çalışmayı düşünmediğini ortaya koymuşlardır. Güzel ve diğerlerinin (2014) Çanakkale Onsekiz Mart Üniversitesi, Mersin Üniversitesi ve KKTC Girne Amerikan Üniversitesi turizm öğrencileri üzerinde yaptıkları araştırma öğrencilerin \%48'inin mezun olduktan sonra turizmde çalışmaya karşı olumsuz ve kararsız bir tutum sergilediklerini göstermektedir. Öğrencilerin \%27'si ise okuldan ayrılma niyetindedir.

Turizm endüstrisine karşı eğitimli personelin bu olumsuz tutumları sektörün eğitimli ve kalifiye personel çalıştırma ve işte alıkoyma sorunu ile karşı karşıya kalacağını göstermektedir. Bu durum da hizmet kalitesini, misafir memnuniyetini ve sadakatini olumsuz etkilemekte, işletmenin nitelikli işgücüne dayanan rekabet avantajını ortadan kaldırmaktadır. Ayrıca işletmelerin işgören eğitim masrafları da artmaktadır. Bu açıdan değerlendirildiğinde turizm eğitimi alan öğrencilerin turizm endüstrisine yönelik algıları ve turizm mesleğine yönelik tutumları hizmetin niteliğini ve sektörün devamlılığını etkilemektedir. Turizm eğitimi alan öğrencilerin sektördeki çalışma şartlarına yönelik değerlendirmeleri ve kariyer algıları, istihdam tercihlerinde ve kariyer gelişimlerinde önemli rol oynamaktadır. Eğitimli personelin sektörün geleceği, hizmet kalitesi ve sürdürülebilirliği üzerindeki öneminden hareketle bu çalışmada önlisans ve lisans eğitimi alan öğrencilerin turizm sektörüne, sektörün çalışma koşullarına yönelik algıları ve bakış açıları belirlenmeye çalışılmıştır. Bu bağlamda çalışmada Karabük Üniversitesi Safranbolu 
Meslek Yüksekokulu ve Safranbolu Turizm Fakültesi öğrencileri üzerinde yapılan ampirik çalışmadan elde edilen sonuçlar paylaşılmıştır.

\section{LİTERATÜR}

İlgili yazında ortaöğretim ve yükseköğretim düzeyinde turizm eğitimi alan öğrencilerin turizm sektörüne yönelik alg1 ve tutumlarını belirlemeye çalışan çok sayıda araştırma bulunmaktadır. Bazı araştırmalarda (Kuşluvan ve Kuşluvan, 2000; Jiang ve Tribe, 2009) turizm eğitimi alan öğrencilerin sektörle ilgili olarak hayal kırıklığı yaşadıkları, aldıkları eğitimi ve staj çalışmalarını zaman, para ve enerji kaybı olarak değerlendirdikleri sonucuna ulaşılmıştır.

Baltacı ve Üngüren'in (2010) Akdeniz Üniversitesi, Süleyman Demirel Üniversitesi ve Balıkesir Üniversitesi'nin turizm eğitimi alan ön lisans, lisans ve yüksek lisans öğrencileri üzerinde yaptıkları bir araştırmada, öğrencilerin genel olarak sektöre karşı olumsuz bir tutum içersinde oldukları saptanmıştır. Benzer şekilde, Pehlivan'ın Adnan Menderes Üniversitesi Turizm İşletmeciliği ve Otelcilik Yüksekokulu öğrencileri üzerinde yaptığ1 araştırma öğrencilerin önemli bir kısmının, turizm bölümünü isteyerek seçmelerine rağmen mezun olduktan sonra turizmde kariyer yapmak istemediklerini ortaya koymaktadır (Güzel ve diğerleri, 2014).

Orhan (2015), turizm lisans eğitimi alan öğrenciler üzerinde yaptığı araştırmada öğrencilerin mesleki geleceklerini turizm sektöründe görmedikleri ve kariyerleri ile ilgili gelecek kaygısı taşıdıkları sonucuna ulaşmıştır. Bu durum lisans düzeyinde turizm eğitimi alan öğrencilerin, başka sektörlerde iş aramalarına neden olmaktadır. Çalışmada lisans düzeyinde turizm eğitimi alan öğrencilerin turizm sektörü ile ilgili algıları ile çalışma niyeti arasında pozitif yönlü anlamlı bir ilişki olduğu, sektöre yönelik olumlu algılar arttıkça öğrencilerin sektörde çalışma niyetinin de arttığı sonucuna ulaşılmıştır.

Konaklama öğrencilerinin turizm kariyerlerinde geleceğe yönelik bakış açılarını ortaya koyan Jenkins (2001) çalışmasında, öğrencilerin \%45'inin gelecekte turizmde çalışacaklarını, mezun olduktan sonra beş ve on yıllık süreçte öğrencilerin genel müdür ve operasyon müdürü pozisyonunda olmak istediklerini belirtmiştir. Ancak öğrencilerin eğitimleri ilerledikçe (üst sinıflara geçtikçe) turizm sektörüne yönelik tutumlarının olumsuzlaştığı görülmektedir. Bununla birlikte bazı araştırmalarda ise öğrencilerin turizm sektörüne yönelik olumlu algıları olduğu sonuçlarına ulaşılmıştır. Roney ve Öztin'in (2007) Türkiye'nin üç faklı üniversitesinde yaptıkları kariyer algısı belirleme çalışmasında, öğrencilerin çoğunluğunun turizm eğitiminin doğru bir kariyer tercihi olduğunu ve bu yolla iyi paralar kazanılabileceğini düşündüklerini ortaya koymuştur.

Chuang ve Jenkins'in (2010) yaptıkları çalışmada, öğrenciler mesleğin sosyal getirileri ve eğlenceli olmasını konaklama sektöründe kariyer yapmak istemelerinin temel nedeni olarak göstermişlerdir. Ancak öğrenciler iş güvenliği ve elde edilen gelir konularında olumsuz algıya sahiptirler. Lu ve Adler'ın (2009) Çin'de yaptığı araştırma ise 
turizm öğrencilerinin sektörde kariyer yapma eğiliminde olduklarını ve özellikle sektörün 'kişisel gelişim sağlama' ve 'yüksek gelir elde etme' özelliklerinden dolayı mezuniyetten sonra sektörde çalışmak istediklerini ortaya koymuştur.

Chen ve arkadaşlarının (2000) Tayvan'da yaptıkları bir araştırmada öğrencilerin \%70'inin sektöre yönelik tutumlarının olumlu olduğu ve turizm sektöründe çalışmak istedikleri saptanmıştır. Benzer şekilde Çavuş ve Kaya'nın (2015) Kırgızistan-Türkiye Manas Üniversitesi turizm öğrencileri üzerinde yaptıkları araştırmada da öğrencilerin turizme yönelik tutumlarının olumlu olduğu sonucuna ulaşılmıştır. Duman ve arkadaşlarının (2006) araştırmasında ise, sektördeki çalışma şartlarını olumsuz olarak değerlendirmelerine rağmen, öğrencilerin \%68'inin geleceklerini turizm sektöründe gördükleri belirlenmiştir.

Kusluvan ve Kusluvan'ın (2000) Nevşehir Turizm ve Otelcilik Yüksekokulu öğrencileri üzerinde yaptığı araştırmada öğrencilerin \%89'unun turizm sektöründe çalışmayı ilginç, \% 85'inin ise yapılmaya değer buldukları sonucuna ulaşılmıştır. Bununla birlikte öğrencilerin sadece yarısı geleceklerini turizm endüstrisinde görmektedir. Öğrencilerin \%42'si ise turizm mesleğini seçmekten memnun olmadiklarını ifade etmişlerdir. Öğrencilerin yarısından fazlası çocuklarının turizm sektöründe çalışmasını istememektedirler.

Öğrencilerin sektöre karşı olumsuz tutumlarının en önemli nedenleri işin stresli olması, aile yaşantısını olumsuz etkilemesi, sektördeki uzun ve yorucu çalışma saatleri, işin sezonluk olması, işin sosyal statüsünün düşük olması, ücretin ve yan gelirlerin düşük olması, terfi imkanlarının kısıtlı olması, verilen eğitimin bu karmaşık sektörde başarılı olmak için yetersiz olması, iş güvencesi ve çalışma garantisi olmaması, eğitimsiz işgörenler ve yöneticiler, yöneticilerin işgörenlere karşı kötü davranışları ve kötü fiziksel koşullardır (Kuşluvan ve Kuşluvan, 2000; Birdir, 2002; Öztürk ve Pelit, 2008; Jiang ve Tribe, 2009; Richardson ve Butler, 2012).

Yapılan araştırmalar sektörde ödenen ücretlerin diğer sektörlere oranla düşük olduğunu göstermektedir. Örneğin; Avrupa Birliği (AB) ülkelerinde turizm sektöründe çalışanlar AB ücret ortalamasının \%20 altında ücret almaktadırlar. Milli Eğitim Bakanlı̆̆1 Mesleki ve Teknik Eğitim Araştırma ve Geliştirme Merkezi Başkanlığı'nın 2000 yılındaki araştırmasında da, sektör çalışanlarının \% 46'sının çalışmanın yapıldığı 2000 yılı asgari ücret ortalaması olan 129.375.000 TL'nin altında, \%22,3'ünün ise yaklaşık olarak asgari ücret düzeyinde ücret aldıkları, turizm eğitimi almış olanların ücretlerinde bir farklılık olmadığı belirlenmiştir. (Duman, Tepeci ve Unur, 2006).

Aksu ve Köksal'in (2005) Antalya Turizm ve Otel İşletmeciliği bölümü öğrencileri üzerinde yaptıkları araştırmada öğrencilerin genel olarak turizm endüstrisine yönelik olumsuz algı ve tutumlara sahip oldukları ortaya çıkmıştır. Öğrencilerin sektörü olumsuz algılamalarının en önemli nedenleri uzun ve düzensiz çalışma saatleridir. Benzer 
sonuçlara Meslek Yüksekokulu Turizm İşletmeciliği ve Otel İşletmeciliği programındaki araştırmalarında Dinçer ve arkadaşları da ulaşmıştır. Duman ve diğerlerinin (2006) Mersin'de yaptıkları araştırmada ise öğrencilerin sektörün çalışma koşullarını ağır, ücret ve ek gelirleri düşük buldukları görülmektedir. Sektörün mevsimlik yapısı, çalışma koşullarının ağır olması, sosyal hakların yetersiz olması, turizm personeli meslek yasasının olmaması gibi nedenlerle sektörde işgören devir oranının yüksek olduğu görülmektedir (Orhan, 2015). Turizmle ilgili işlerde çalışanlar herhangi bir yasal düzenlemeyle korunmadıkları için turizm eğitimi alan işgücü başka sektörlere yönelmektedir (Gharamaleki, 2011).

Turizmle ilgili işlerin saygın bir meslek olarak algılanmaması kişilerin sektörde çalışmasını olumsuz etkilemektedir. Kozak ve Kızılırmak (2001), Birdir (2002) ve Roney ve Öztin'in (2007) önlisans öğrencileri üzerinde yaptıkları araştırmada öğrencilerin turizm sektöründeki işlerin saygınlığı konusunda olumsuz tutuma sahip oldukları bulgusuna ulaşılmıştır. Yapılan araştırmalar turizm sektöründeki işlerin pek çok toplumda saygınlığ1 düşük olarak algılandığını (Boella, 2000), bu durumun sektörün iyi eğitimli işgücünü istihdam etmesine engellediğini (Lee ve Kang, 1998) yönetim kademeleri hariç turizmdeki diğer işlerin yüksek statülü işler olarak düşünülmediğini (Pizam ve Telisman-Kosuta, 1989) ortaya koymuştur. Sektörde ücretlerin düşük, çalışma saatlerinin uzun, yorucu ve düzensiz olması, iş güvencesinin yetersiz olması, işgücü devir hızının yüksek olması, eğitime gereken önemin verilmemesi ve sektörde yoğun olarak gençlerin istihdam edilmesi sektörün saygınlığının düşük olarak algılanmasının başlıca nedenleridir (Duman, Tepeci ve Unur, 2006)

Öğrencilerin farklı üniversitelerde ve şehirlerde eğitim görmeleri, turizmde kariyer algılarını farklılaştıran bir unsurdur. Farklı şehirler ve farklı üniversitelerde turizm eğitimi gören öğrenciler üzerinde yapılan karşılaştırmalı çalışmalarda (Roney ve Öztin, 2007; Güzel ve diğerleri, 2014) farklı üniversitelerde eğitim gören öğrencilerin turizm sektör algıları arasında istatistiksel olarak anlamlı farklılık bulunmuştur.

Literatürde demografik değişkenlere göre turizm algısının farklılık yaratıp yaratmadığı konusunda yapılan analizlerde ise farklı sonuçlara ulaşılmıştır. Örneğin; Roney ve Oztin (2007) ve Kozak ve Kızılırmak (2001), Güzel ve diğerleri (2014) cinsiyetin turizm algısı üzerinde fark yaratmadığı sonucuna ulaşmışlardır. Ancak Aymankuy ve Aymankuy'un (2013) çalışmasında cinsiyetler itibariyle algının farklılaştı̆̆ı sonucuna ulaşılmıştır.

\section{METODOLOJI}

Araştırmanın evrenini, Karabük Üniversitesi Turizm Fakültesi Turizm İşletmeciliği bölümü öğrencileri ile Safranbolu Meslek Yüksekokulu Turizm ve Otel İşletmeciliği ve Turizm Animasyonu programlarında okuyan toplam 653 öğrenci oluşturmaktadır. Araştırmada öğrencilerin turizm endüstrisine yönelik algılarının belirlenmesi 
amaçlanmıştır. Araştırmada ayrıca katılımcıların demografik özellikleri ile turizm hakkındaki düşünceleri arasındaki farklılıklar da incelenmeye çalışılmıştır. Dolayısıyla araştırmada “Karabük Üniversitesi Turizm Bölümü'nde eğitim gören öğrencilerin sektörün çalışma koşulları, kişi-turizm uyumu, sosyal statü ve terfi imkanları, yönetici-iş arkadaşları, ücret-ek ödemeler, motivasyon ve özel hayat hakkındaki görüşleri nelerdir ve bu hususlar öğrencilerin demografik özelliklerine göre farklılık göstermekte midir?" sorusuna cevap aranmaya çalışılmıştır.

2016 yılı Nisan-Mayıs ayları arasında yapılan araştırmada kolayda örnekleme yöntemi kullanılmıştır. Örneklem büyüklüğünün hesaplanmasında Krejcie ve Morgan (1970)'ın değerlendirmelerin oranlara göre yapıldığı araştırmalar için önerdikleri tablodan yararlanılmıştır. Söz konusu tabloda, 0,05 anlamlılık düzeyi ve $\pm 0,05$ hata oranında, evren hacminin 650 olması halinde örneklem büyüklüğü 242 olarak belirtilmiş olup bu araştırmada örneklem 393 kişiden oluşmaktadır.

Araştırmada anket tekniği kullanılmış olup anket formu, Duman, Tepeci ve Unur (2006), Kuşluvan ve Kuşluvan (2003) ve Riegel ve Dallas (1998)'ın çalışmalarından yararlanılarak hazırlanmıştır. Anket formu iki bölümden oluşmaktadır. Birinci bölümde, öğrencilerin cinsiyetleri, turizm eğitim programı, bölüm seçimini etkileyen kişi/kişiler, sektör deneyimi, ailede turizm sektöründe çalışan olup olmadığ gibi beş soruyu cevaplamaları istenmiştir. İkinci bölümde ise öğrencilerin turizme yönelik algılarının belirlenmesi amacıyla 36 önermeden oluşan ve 5'li Likert ölçeğinde (1-Kesinlikle Katılmıyorum; 5-Kesinlikle Katılıyorum) hazırlanan ifadelere yer verilmiştir. Araştırmada kullanılan ölçek faktör analizine tabi tutulmuştur. Bu kapsamda geçerlik ve güvenirliğine yönelik bulgular Tablo 1'de sunulmuştur. Aynı tabloda ölçeğin güvenirliği Cronbach Alpha katsayılarına göre $\alpha=0,70$ 'in üzerinde olduğundan (Kalaycl, 2010) ölçeğin yüksek güvenilirlikte olduğu söylenebilir.

Elde edilen veriler SPSS 20 for Windows paket programı kullanılarak analiz edilmiştir. İfadelerin faktör yükleri ile Kaiser-Meyer-Olkin (KMO) ve güvenirlik analizi için Cronbach Alpha değerleri saptanmıştır. Ancak hem verilerin normal dağılımına (Kolmogorov-Smirnov Test) hem de homojenliğine (Levene) ilişkin testler yapıldığında, p değerlerinin 0,05'ten küçük olduğu tespit edilmiş, dolayısıyla veriler parametrik test koşulları sağlanmadığı için parametrik olmayan testler bağımsız iki grubun karşılaştırılmasında Mann-Whitney U Testi, birbirinden bağımsız ikiden fazla grubun karşılaştırılmasında ise Kruskal-Wallis H Testi kullanılarak analiz edilmiştir.

\section{ARAŞTIRMANIN BULGULARI}

Araştırmaya katılanların 167'si kadın (\%42), 226'sı ise erkektir (\%58). 154'ü lisans (\%39) ve 239'u ön lisans (\% 61) öğrencisidir. Öğrencilerden 207'si kendi seçimleri doğrultusunda (\% 53), 46's1 ailesinin (\%12), 52'si arkadaşlarının (\%13), 39'u rehber öğretmenin (\% 10) etkisi ve yönlendirmesiyle ve $49^{\prime} \mathrm{u}$ ise yatay geçiş hakkı (\% 12) ile 
turizm alanını seçtiklerini belirtmişlerdir. Öğrencilerden 162'si sektör deneyimi (\% 41) olduğunu belirtirken, 231'i sektör deneyimi olmadığını (\% 59) ifade etmiştir. Öğrencilerden 104'ünün ailesinde (\% 26) turizm sektöründe istihdam edilen işgörenler bulunmaktadır. Benzer biçimde Erdinç (2012) de araştırmasında öğrencilerin \%68'inin turizm sektöründe çalışan akraba veya arkadaşının olmadığı sonucuna ulaşmıştır.

Tablo 1'de ölçeğin yapı geçerliğine ilişkin varimax rotasyonu ve temel bileşenler (principal components) yöntemi kullanılarak yapılan faktör analizi, Cronbach's Alpha değerleri ve ifadelere ilişkin aritmetik ortalama değerleri sunulmuştur. 
Tablo 1.Turizm Algısına Yönelik Faktör Analizi

\begin{tabular}{|c|c|c|c|c|c|}
\hline FAKTÖRLER & Faktör Yükleri & Öz Değer & $\begin{array}{c}\text { Açılanan } \\
\text { Varyans }\end{array}$ & $\begin{array}{c}\text { Cronbach } \\
\text { Alpha }\end{array}$ & $\overline{\mathrm{X}}_{/ \mathrm{S} . \mathrm{D}}$ \\
\hline \multicolumn{6}{|l|}{ Çalışma Koşulları (İşin Doğası) } \\
\hline Turizm endüstrisinde çalışma saatleri düzensizdir & ,754 & \multirow{6}{*}{10,187} & \multirow{6}{*}{30,869} & \multirow{6}{*}{,839 } & $3,92 / 1,10$ \\
\hline Turizm sektöründeki çalışma ortamı streslidir & ,707 & & & & $3,81 / 1,11$ \\
\hline Turizm sektöründe çalışma saatleri çok uzundur & ,658 & & & & $3,91 / 1,06$ \\
\hline Mevsimsellik özelliğinden dolayı turizm sektöründe daimi bir iş bulmak zordur & 629 & & & & $3,82 / 1,10$ \\
\hline Turizm endüstrisindeki işler çok yorucudur &, 574 & & & & $3,95 / 0,98$ \\
\hline Sektörde çalışarak aile yaşantısını sürdürmek zordur &, 535 & & & & $3,78 / 1,02$ \\
\hline \multicolumn{6}{|l|}{ Kişi-Turizm Sektörü Uyumu } \\
\hline Turizm sektöründeki işlerde bilgi ve becerilerimi kullanabilirim & 807 & \multirow{5}{*}{2,723} & \multirow{5}{*}{8,252} & \multirow{5}{*}{ 799 } & $3,81 / 1,06$ \\
\hline Kişiliğim turizm endüstrisinde çalışmaya uygundur & ,765 & & & & $3,73 / 1,06$ \\
\hline Tempolu iş ortamını severim & 644 & & & & $3,79 / 1,04$ \\
\hline İnsanlara hizmet etmek beni mutlu eder & ,634 & & & & $3,64 / 1,14$ \\
\hline Kisa sürede sektörde iyi noktalara geleceğimi düşünüyorum & 469 & & & & $3,77 / 1,06$ \\
\hline \multicolumn{6}{|l|}{ Sosyal Statü ve Terfi İmkânları } \\
\hline Sektörde turizm eğitimi almayan çalışanlar alanlarla geçinemezler & 636 & \multirow{6}{*}{2,063} & \multirow{6}{*}{6,251} & \multirow{6}{*}{0,782} & $3,55 / 1,15$ \\
\hline Turizm sektöründe çalışmak toplumda fazla saygı görmüyor &, 592 & & & & $3,61 / 1,16$ \\
\hline Sektörde tanıdığı (torpili) olmayanın terfi etmesi zordur & ,581 & & & & $3,67 / 1,11$ \\
\hline Turizm sektöründe çalışmak ahlaki değerlerden ödün vermeyi gerektirir & ,568 & & & & $3,39 / 1,30$ \\
\hline Sektörde terfi imkânları kısıtlıdır & ,551 & & & & $3,62 / 1,10$ \\
\hline Çalışanlar terfi ettirilirken tecrübeleri dikkate alınır & 408 & & & & $3,82 / 1,07$ \\
\hline \multicolumn{6}{|l|}{ Yöneticiler ve İş̧ Arkadaşları } \\
\hline $\begin{array}{l}\text { Yöneticiler çalışanların işletmeye olan bağlılıklarını arttırmak için yeterli çaba } \\
\text { göstermez }\end{array}$ & ,772 & \multirow{5}{*}{1,596} & \multirow{5}{*}{4,836} & \multirow{5}{*}{,784 } & $3,53 / 1,15$ \\
\hline Turizm sektörü çalışanlarında ekip ruhu gelişmemiştir & 683 & & & & $3,40 / 1,27$ \\
\hline Turizm sektöründe çalışanların genelde eğitim seviyesi düşüktür & ,667 & & & & $3,49 / 1,15$ \\
\hline Sektörde çalışan yöneticilerin birçoğu turizm eğitimi almamışlardır & ,653 & & & & $3,64 / 1,16$ \\
\hline Turizm sektöründe genelde çalışanlar arasında işbirliği vardır & 626 & & & & $3,78 / 1,03$ \\
\hline
\end{tabular}

*Yazışma adresi: E-mail: nturker@karabuk.edu.tr 
N. Turker, M. Uçar..... / Karabük Üniversitesi Sosyal Bilimler Enstitüsü Dergisi, 2016, 6 (2), 311-333

\section{Ücret ve Ek Ödemeler}

\begin{tabular}{|c|c|c|c|c|c|}
\hline $\begin{array}{l}\text { Bu sektördeki birçok işin ücreti ekonomik olarak rahat bir hayat sürmek için } \\
\text { yetersizdir }\end{array}$ & 738 & \multirow{5}{*}{1,198} & \multirow{5}{*}{3,629} & \multirow{5}{*}{819} & $3,72 / 1,02$ \\
\hline Bu sektörde çok para kazanabileceğimi düşünmüyorum & 717 & & & & $3,59 / 1,13$ \\
\hline Sektör dışındaki ek gelirler (prim, konaklama, ulaşım, ikramiye) yetersizdir & 614 & & & & $3,82 / 1,01$ \\
\hline Turizm sektöründeki birçok işin ücreti çok düşüktür &, 581 & & & & $3,64 / 1,11$ \\
\hline Daha önceki mezunlar sektörde iyi pozisyonlarda değiller & ,426 & & & & $3,66 / 1,07$ \\
\hline \multicolumn{6}{|l|}{ Motivasyon } \\
\hline Turizm sektöründe fiziksel çalışma koşulları genelde iyidir & 674 & \multirow{3}{*}{1,092} & \multirow{3}{*}{3,309} & \multirow{3}{*}{,732 } & $3,59 / 1,09$ \\
\hline Sektörde çalışanların çalışma isteği ve motivasyonu yüksektir & 656 & & & & $3,71 / 1,07$ \\
\hline Turizm sektöründe çalışmayı eğlenceli buluyorum & ,539 & & & & $4,02 / 1,05$ \\
\hline \multicolumn{6}{|l|}{ Özel Hayat } \\
\hline Özel hayatım benim için çok önemlidir & ,727 & \multirow{3}{*}{1,015} & \multirow{3}{*}{3,077} & \multirow{3}{*}{ 692 } & $4,15 / 1,05$ \\
\hline Hafta sonu tatili benim için çok önemlidir & 610 & & & & $4,12 / 1,10$ \\
\hline \multirow[t]{2}{*}{ Turizmde çalışmak toplumda garsonluk mesleği ile eşdeğer olarak algılanıyor } &, 586 & & & & $3,96 / 1,12$ \\
\hline & & & 60,223 & ,928 & \\
\hline
\end{tabular}


Araştırmada turizm bölümünde okuyan öğrencilerin turizme ilişkin bakış açılarını boyutlandırabilmek amacıyla temel bileşenler (principal components) yöntemi ve varimax rotasyonu kullanılarak faktör analizi yapılmıştır. Öğrencilerin turizme yönelik algılarını ölçen 36 önerme kullanılarak yapılan faktör analizinde, 7 faktör elde edilmiştir. Ancak bu 7 faktör için yapılan içerik analizi sonucunda düşük yüklenme değerine (<.40) sahip ve/veya çapraz yüklenen üç önerme (11., 24. ve 26. önermeler) bir sonraki faktör analizine dâhil edilmemiştir. Kalan 33 önermenin faktör analizine tabi tutulması sonucunda yüklenme değeri 0,40 'ın ve özdeğeri 1'in üzerinde toplam varyansın yaklaşık \%60'ını açıklayan 7 faktör elde edilmiştir. Kaiser-Meyer-Olkin örneklem yeterliliği, $0,920 \quad(\mathrm{p}<.000)$, verinin faktör analizine uygun olduğunu göstermektedir. Kalaycı'ya (2010) göre bu değerler faktör analizi uygulamak için yeterli seviyede kabul edilmektedir. Eroğlu (2005) 350 ve üzerindeki veri sayısı için faktör ağırlığının 0,30 ve üzerinde olması gerektiğini belirtmektedir. Bu araştırmadaki ifadelerin tüm faktör yükleri kabul edilen bu değerlerin üzerinde olduğundan faktör yükleri kabul edilebilir seviyededir. Ayrıca hem alt boyutların hem de genel ölçek güvenilirliğinin değerleri de 0,70'in üzerinde olduğu için ölçeklerin iç tutarlılık düzeylerinin yeterli olduğu (Kayış, 2009) söylenebilir.

Tablo 1, her bir faktördeki maddelerin yüklenme değerini, her bir faktörün özdeğerini, açıkladığı varyansı, faktörlerin güvenirlik (iç tutarlılık) değerlerini ve ölçeğe ilişkin ifadelerin aritmetik ortalamalarını göstermektedir. Faktör analizi sonuçları beklenen faktör yapısından farklılıklar göstermektedir. Verinin analizinde en yüksek varyansı açıklayan (\%30.869) Faktör 1 (Çalışma Koşulları/İşin Doğası), 6 ifadenin bir araya gelmesiyle oluşmuştur. Bu ifadeler, beklenildiği gibi çalışma saatlerinin uzunluğu ve düzensizliği, çalışma ortamının stresli ve işlerin yorucu olması, turizmin mevsimlik özelliğinden dolayı daimi olarak çalışmanın ve aileyi geçindirmenin zor oluşu gibi hususları bir araya getirmiştir. Faktör 2 (Kişi-Turizm Sektörü Uyumu) varyansın \%8.252'ini açıklamakta olup 5 önermeden oluşmuştur. "Kısa sürede sektörde iyi noktalara geleceğimi düşünüyorum" ifadesi terfi imkânı ile ilgili olmakla beraber bu önerme anlam olarak incelendiğinde, kişinin aldığ turizm eğitiminin bir sonucu olarak kendisine güvendiğinin ve gerekli uyumu sağlayarak kısa sürede yüksek bir pozisyonda çalışabileceğinin bir göstergesi olarak açılanabilir. Varyansın \%6.251'ini açıklayan Faktör 3 (Sosyal Statü/Terfi İmkânları) 6 önermeden oluşmuştur. Üç sosyal statü ve iki terfi imkânı ifadesine ek olarak, yöneticiler ve iş arkadaşları boyutunda yer alması beklenen "Sektörde turizm eğitimi almayan çalışanlar, eğitim alanlarla geçinemezler" ifadesi bu faktöre yüklenmiştir. Bu ifadede "eğitim almak" kavram olarak sosyal statü göstergesi olarak algılanmış olabilir.

Faktör 4 (Yöneticiler ve İş Arkadaşları) varyansın \%4.836'sını açıklamakta olup 5 önermeyi içermektedir. Bu faktör öğrencilerin birlikte çalışacakları yönetici ve iş arkadaşları ile ilgili hususları birlikte değerlendirdiklerini göstermektedir. Varyansın \%3,629'unu açıklayan Faktör 5 (Ücret ve Ek Ödemeler) 5 önermeden oluşmaktadır. Ancak terfi imkânı olarak düşünülen "Daha önceki mezunlar sektörde iyi pozisyonlarda değildirler" önermesi bu faktör altında çıkmıştır. Faktör 6 (Motivasyon) varyansın \%3.309'unu açıklamakta ve 3 önermeden oluşmuştur. Son olarak, varyansın \%3,077'ini 
açıklayan Faktör 7 (Özel Hayat), hafta sonu tatilinin özel hayat için ayrılan zamanı ifade etmesi ve özel hayatın çalışanlar açısından önemli olması nedeniyle bu şekilde isimlendirilmiştir. Bununla birlikte "Turizmde çalışmak toplumda garsonluk mesleği ile eşdeğer olarak algılanıyor" ifadesi sosyal statü boyutu altında çıkması beklenirken, bu boyutta çıkmıştır.

Tablo 1'deki aritmetik ortalama sonuçlarına göre öğrencilerin turizm sektörü ile ilgili algıları şu şekilde özetlenebilir;

Öğrenciler sektörde çalışma koşullarının iyi olmadığına, işin zor ve stresli olduğuna inanmaktadırlar. Önermelere verilen cevapların aritmetik ortalamaları dikkate alındığında turizm endüstrisinde çalışma saatleri düzensiz $(\bar{X}=3,92)$, çalışma ortamı stresli $(\bar{X}=3,81)$, çalışma saatleri ise çok uzundur $(\bar{X}=3,91)$. Ayrıca öğrenciler, mevsimlik özelliği nedeniyle turizm sektöründe daimi bir iş bulmanın $(\overline{\mathrm{X}}=3,82)$, turizm endüstrisindeki işlerin $(\overline{\mathrm{X}}=3,95)$ ve sektörde çalışarak aile yaşantısını sürdürmenin çok zor $(\bar{X}=3,78)$ olduğunu düşünmektedirler. Elde edilen sonuçlar sektördeki çalışma koşullarının ağır olduğunu göstermektedir. Benzer sonuçlara Duman ve arkadaşları (2006), Çavuş ve Kaya (2013) ile Kuşluvan ve Kuşluvan'ın (2000) çalışmalarında da ulaşılmış olup Kuşluvan ve Kuşluvan'ın çalışmasında araştırmaya katılan öğrencilerin \%77'si turizm mesleğinin stresli, \%68'i yorucu olduğunu, \%79'u ise çalışma saatlerinin uzun olduğunu ifade etmiştir. Benzer biçimde öğrencilerin \%87'isi aile yaşamının iş koşullarından olumsuz etkilendiğini ve \%87'si turizmin mevsimlik özelliği nedeniyle sektörde sürekli bir iş bulmanın zor olduğunu belirtmişlerdir. Keza Duman ve arkadaşlarının (2006) çalışmasında da "işin doğası ve çalışma koşulları" boyutu öğrencilerin sektöre yönelik olarak en çok olumsuzladıkları faktördür.

Öğrenciler, turizm sektöründeki işlerde bilgi ve becerilerini kullanabileceklerine $(\bar{X}=3,81)$, kişilik yapılarını turizm ile uyumlu olduğuna $(\bar{X}=3,73)$ inanmakta, tempolu iş ortamını sevdiklerini $(\bar{x}=3,79)$, insanlara hizmet etmenin mutluluk kaynağı olduğunu $(\bar{X}=3,64)$ ifade etmekte ve kısa sürede sektörde iyi noktalara geleceklerine $(\overline{\mathrm{x}}=3,77)$ inanmaktadırlar. Bu durum öğrencilerin mesleği yapabilecek kapasite ve nitelikte olduklarına inandıklarını göstermektedir. Nitekim Aymankuy ve Aymankuy (2013) da çalışmalarında benzer sonuçlara ulaşmış olup öğrenciler sektöre yönetici pozisyonuna geleceklerine inandıklarını ifade etmişlerdir. Bununla birlikte Kuşluvan ve Kuşluvan'ın (2000) çalışmasında çelişkili sonuçlara ulaşılmış olup öğrencilerin \%77'si turizmde yetenek ve becerilerini kullanabildiklerini, \%73'ü sektörün kişilik yapısına uygun olduğunu, \%94'ü misafirlere hizmet etmekten memnun olduklarını belirtirken; \%68'i kendilerini köle gibi hissettiklerini ve \%78'i ise insanlara hizmet etmenin iyi bir his olmadığını ifade etmişlerdir.

Öğrenciler, sektörde turizm eğitimi almayan çalışanlar ile turizm eğitimi alanların geçinemediklerine $(\bar{X}=3,55)$, turizm sektöründe çalışmanın toplumda fazla sayg1 görmediğine $(\overline{\mathrm{X}}=3,61)$ inanmaktadırlar. Benzer bir sonuca Kuşluvan ve Kuşluvan'ın (2000) çalışmasında da ulaşılmış olup araştırmaya katılan turizm öğrencilerinin \%51'inin turizmin prestijli bir meslek olmadığına inandıklarını ortaya koymaktadır. Literatürdeki diğer araştırmalar da (Jiang ve Tribe, 2009; Kozak ve 
Kızılırmak, 2001) turizm eğitimi alan öğrencilerin, turizm sektöründe çalışanların sosyal saygınlıkları konusunda olumsuz tutuma sahip oldukları görülmektedir. Ancak Duman ve arkadaşlarının (2006) çalışmasında öğrencilerin sektörün saygınlığı düşük bir sektör olduğuna inanmadıkları sonucuna ulaşılmıştır. Bu araştırmaya katılan öğrenciler ayrıca sektörde tanıdığı (torpili) olmadan terfi etmenin zor $(\bar{X}=3,67)$ olduğunu ifade etmektedirler. Bununla birlikte öğrencilerin, turizm sektöründe çalışmanın ahlaki değerlerden ödün vermeyi gerektirdiği görüşüne kısmen katıldıkları görülmektedir ( $\bar{X}=3,39)$. Öğrenciler, sektörde terfi imkânlarının kısıtlı $(\bar{X}=3,62)$ olduğuna inanmakta, ancak çalışanların terfi ettirilirken tecrübelerinin dikkate alındığını düşünmektedirler $(\bar{X}=3,82)$. Bu durum, öğrencilerin yeterli mesleki bilgi, beceri ve donanıma sahip olsalar dahi terfi etme ile ilgili olarak olumsuz algilarının olduğunu göstermektedir. Orhan (2015) ile Kuşluvan ve Kuşluvan'in (2000) çalışmasında da benzer bulgulara ulaşılmış olup çalışmalarda, terfi imkanlarının tatmin edici olmadığı, terfi etmede adil davranılmadığı ve terfilerin hak edişe göre yapılmadığı, yönetsel görevlere terfi etmenin sınırlı olduğu, torpil olmadan terfi etmenin çok zor olduğu sonuçlarına ulaşılmıştır.

Öğrencilerin, çalışanların işletmeye olan bağlılıklarını arttırmak için yöneticilerin yeterli çaba gösterdikleri $(\overline{\mathrm{X}}=3,53)$, turizm sektörü çalışanları arasında ekip ruhunun gelişmemiş olduğu $(\overline{\mathrm{X}}=3,40)$ ve çalışanların genelde eğitim seviyesinin düşük olduğu $(\bar{X}=3,49)$ önermeleri ile ilgili olarak kararsız kaldıkları görülmektedir. $\mathrm{Bu}$ kararsızlığın temel nedeni, araştırmaya katılan öğrencilerin çoğunluğunun sektör deneyimi olmayan katılımcılardan oluşması olabilir. Öğrenciler, sektörde çalışan yöneticilerin birçoğunun turizm eğitimi almadığını $(\bar{X}=3,64)$ ancak genelde çalışanlar arasında işbirliğinin var olduğunu $(\overline{\mathrm{X}}=3,78)$ düşünmektedirler. Bu durum, öğrencilerin sektörde eğitimli-alaylı çatışmasının var olduğu yönünde bir algıya sahip olduklarını göstermektedir. Kuşluvan ve Kuşluvan'ın (2000) çalışmasında üniversite eğitimi almayan turizm çalışanlarının (alaylı) turizm alanında üniversite eğitimi alanları kıskandığı bulgusuna ulaşılmıştır. Ayrıca turizm bölümü öğrencilerinin \%83'ü sektörde turizm eğitimi almayan personelin çalıştığına inanmaktadırlar. Bunun yanısıra çalışmada öğrencilerin yöneticilerle ilgili algılarının olumsuz olduğu; yöneticilerin işgören bağlılığını arttırma konusunda çaba göstermedikleri, pek çok yöneticinin turizm eğitimi almamış olduğu, işgörenlere ve onların önerilerine değer vermedikleri, işgörenlere adil davranmadıkları ve işgörenlerin iş tatminine önem vermedikleri ortaya çıkmıştır.

Öğrenciler sektörde elde edilen gelirlerin tatminkar olmadiğına inanmaktadırlar. Öğrenciler, turizm sektöründe ödenen ücretin, ekonomik olarak rahat bir hayat sürmek için yetersiz olduğuna $(\bar{X}=3,72)$, sektörden çok para kazanılmadığına $(\bar{X}=3,59)$, ek gelirlerin (prim, konaklama, ulaşım, ikramiye) yetersiz ve $(\bar{X}=3,82)$, ücretin çok düşük $(\overline{\mathrm{X}}=3,64)$ olduğuna inanmaktadırlar. Bu çalışmada ayrıca öğrenciler daha önceki mezunların da sektörde iyi pozisyonlarda olmadıklarına $(\bar{X}=3,66)$ inanmaktadırlar. Bu bulgular Aymankuy ve Aymankuy (2013), Kuşluvan ve Kuşluvan (2000) ve Orhan'ın (2015) çalışmasında elde ettiği bulgularla örtüşmektedir. Aymankuy ve Aymankuy'un (2013) Balıkesir'de yaptığı çalışmada öğrenciler ücretlerin ücretler 
yeterli ve tatminkar olmadığını belirtmişlerdir. Kuşluvan ve Kuşluvan'ın (2000) çalışmasında ise öğrencilerin \% 92'si aldıkları ücreti düşük bulmakta, \%83'ü ise maaş dışındaki yararların (yemek, tatiller v.b.) yetersiz olduğunu düşünmektedir. Sektörde çalışanlara ödenen ücretlerin düşük olması ve sosyal hakların yeterince verilmemesi öğrencilerin sektörle ilgili algılarının olumsuz olmasına neden olmaktadır.

Öğrenciler, turizm sektöründe fiziksel çalışma koşullarının (ısıtma, soğutma, 1şık, bina v.b.) iyi $(\bar{x}=3,59)$, çalışanların çalışma isteği ve motivasyonunu yüksek $(\bar{x}$ $=3,71)$ ve sektörde çalışmayı eğlenceli $(\bar{X}=4,02)$ bulmaktadırlar. Nitekim Aymankuy ve Aymankuy'un (2013) ve Orhan'ın (2015) çalışmaları da sektörün öğrenciler tarafından zevkli ve eğlenceli olarak algılandığını göstermektedir. Sektörün eğlenceli olarak algılanması, öğrencilerin bu mesleği seçmelerinde etkili olan faktörlerin başında gelmektedir.

Öğrencilerin, özel hayatlarına $(\overline{\mathrm{X}}=4,15)$, hafta sonu tatillerine çok önem verdikleri $(\overline{\mathrm{X}}=4,12)$ görülmektedir. $\mathrm{Bu}$ durumda öğrencilerin sektörün düzensiz çalışma koşullarından olumsuz etkilenebilecekleri söylenebilir. Ayrıca öğrenciler turizmde çalışmanın toplumda garsonluk mesleği ile eşdeğer olarak algılandığına ( $\overline{\mathrm{X}}$ $=3,96$ ) inanmakta olup öğrencilerin turizm sektörünün toplumda sosyal statüsü düşük bir meslekler grubu olarak algılanmasından rahatsız oldukları söylenebilir.

Tablo 2. Öğrencilerin Cinsiyetlerine Göre Turizme Yönelik Algılarının Karşılaştırılması (Mann-Whitney U Testi)

\begin{tabular}{|c|c|c|c|c|c|c|}
\hline Boyutlar & Cinsiyet & $\mathbf{N}$ & $\begin{array}{c}\text { Sıralama } \\
\text { Değeri } \\
\text { Ortalaması } \\
\end{array}$ & $\begin{array}{c}\text { S1ralama } \\
\text { Değerleri } \\
\text { Toplamı }\end{array}$ & $\begin{array}{c}\text { Mann- } \\
\text { Whitney U }\end{array}$ & $\mathbf{P}$ \\
\hline \multirow{2}{*}{$\begin{array}{l}\text { Çalışma } \\
\text { Koşulları }\end{array}$} & Kadın & 167 & 191,24 & 31937,50 & \multirow{2}{*}{17909,500} & \multirow{2}{*}{0,386} \\
\hline & Erkek & 226 & 201,25 & 45483,50 & & \\
\hline \multirow{2}{*}{$\begin{array}{l}\text { Kişi-Turizm } \\
\text { Uyumu }\end{array}$} & Kadın & 167 & 191,33 & 31952,00 & \multirow{2}{*}{17924,000} & \multirow{2}{*}{0,393} \\
\hline & Erkek & 226 & 201,19 & 45469,00 & & \\
\hline \multirow{2}{*}{$\begin{array}{c}\text { Sosyal Statü- } \\
\text { Terfi }\end{array}$} & Kadın & 167 & 187,55 & 31321,00 & \multirow{2}{*}{17293,000} & \multirow{2}{*}{0,155} \\
\hline & Erkek & 226 & 203,98 & 46100,00 & & \\
\hline \multirow{2}{*}{$\begin{array}{c}\text { Yönetici ve İş } \\
\text { Arkadaşları }\end{array}$} & Kadın & 167 & 187,17 & 31257,50 & \multirow{2}{*}{17229,500} & \multirow{2}{*}{0,139} \\
\hline & Erkek & 226 & 204,26 & 46163,50 & & \\
\hline \multirow{2}{*}{$\begin{array}{l}\text { Ücret ve Ek } \\
\text { Ödemeler }\end{array}$} & Kadın & 167 & 187,84 & 31369,50 & \multirow{2}{*}{17341,500} & \multirow{2}{*}{0,168} \\
\hline & Erkek & 226 & 203,77 & 46051,50 & & \\
\hline \multirow{2}{*}{ Motivasyon } & Kadın & 167 & 192,48 & 32144,50 & \multirow{2}{*}{18116,500} & \multirow{2}{*}{0,494} \\
\hline & Erkek & 226 & 200,34 & 45276,50 & & \\
\hline \multirow{2}{*}{ Özel Hayat } & Kadın & 167 & 190,29 & 31779,00 & \multirow{2}{*}{17751,000} & \multirow{2}{*}{0,308} \\
\hline & Erkek & 226 & 201,96 & 45642,00 & & \\
\hline
\end{tabular}

${ }^{*} p<0,05$

Öğrencilerin cinsiyetlerine göre turizme (çalışma koşulları, kişi-turizm uyumu, sosyal statü-terfi, yönetici ve iş arkadaşları, ücret ve ek ödemeler, motivasyon ve özel hayat) yönelik algılarının anlamlı bir farklılık gösterip göstermediğini belirleyebilmek için yapılan Mann-Whitney $U$ testi sonuçları Tablo 2'de görülmektedir. Test 
sonuçlarına göre, kadın ve erkeklerin çalışma koşulları $(u=17909,5 ; p>0,05)$, kişi-turizm uyumu ( $u=17924,0 ; p>0,05)$, sosyal statü-terfi $(u=17293,0 ; p>0,05)$, yönetici ve iş arkadaşları ( $\mathrm{u}=17229,5 ; \mathrm{p}>0,05)$, ücret ve ek ödemeler $(\mathrm{u}=17341,5 ; \mathrm{p}>0,05)$, motivasyon $(u=18116,5 ; p>0,05)$ ve özel hayat $(u=17751,0 ; p>0,05)$ boyutlarındaki görüşleri arasında anlamlı bir farklılık bulunamamıştır. Sıralama değeri ortalaması incelendiğinde, tüm boyutlarda erkeklerin ve kadınların turizme yönelik algılarının aynı düzeyde olduğu söylenebilir. Kozak ve Kızılırmak'ın (2001) çalışmalarında da benzer sonuçlara ulaşılmıştır. Bununla birlikte Aymankuy ve Aymankuy (2013) turizm öğrencilerine yönelik olarak yaptıkları çalışmalarında turizm sektörüne yönelik algının kadınlar ve erkekler arasında erkekler lehine anlamlı farklılık gösterdiğini saptamışlardır. Benzer şekilde Duman ve arkadaşları (2006) da erkek öğrencileri kız öğrencilere göre, kişiendüstri uyumu ve terfi imkanları, yetki devri ve motivasyon, yöneticiler ve iş arkadaşları ve sektörde kariyer yapma isteği açılarından daha olumlu olduklarını bulmuşlardır. Bununla birlikte Ross (1994), turizm mesleğine yönelik olarak kız öğrencilerin daha olumlu ve istekli olduklarını ortaya koymuştur.

Tablo 3. Öğrencilerin Eğitimine Göre Turizme Yönelik Algılarının Karşılaştırılması (Mann-Whitney U Testi)

\begin{tabular}{|c|c|c|c|c|c|c|}
\hline Boyutlar & Eğitim & $\mathbf{N}$ & $\begin{array}{c}\text { Siralama } \\
\text { Değeri } \\
\text { Ortalaması } \\
\end{array}$ & $\begin{array}{c}\text { Siralama } \\
\text { Değerleri } \\
\text { Toplamı }\end{array}$ & $\begin{array}{c}\text { Mann- } \\
\text { Whitney U }\end{array}$ & $\mathbf{P}$ \\
\hline \multirow{2}{*}{$\begin{array}{l}\text { Çalışma } \\
\text { Koşulları }\end{array}$} & Önlisans & 154 & 174,01 & 26798,00 & \multirow{2}{*}{14863,000} & \multirow{2}{*}{$0,001^{*}$} \\
\hline & Lisans & 239 & 211,81 & 50623,00 & & \\
\hline \multirow{2}{*}{$\begin{array}{l}\text { Kişi-Turizm } \\
\text { Uyumu }\end{array}$} & Önlisans & 154 & 182,91 & 28168,00 & \multirow{2}{*}{16233,000} & \multirow{2}{*}{$0,048^{*}$} \\
\hline & Lisans & 239 & 206,08 & 49253,00 & & \\
\hline \multirow{2}{*}{$\begin{array}{c}\text { Sosyal Statü- } \\
\text { Terfi } \\
\end{array}$} & Önlisans & 154 & 155,77 & 23988,00 & \multirow{2}{*}{12053,000} & \multirow{2}{*}{$0,000^{*}$} \\
\hline & Lisans & 239 & 223,57 & 53433,00 & & \\
\hline \multirow{2}{*}{$\begin{array}{c}\text { Yönetici ve İşs } \\
\text { Arkadaşları }\end{array}$} & Önlisans & 154 & 156,92 & 24166,00 & \multirow{2}{*}{12231,000} & \multirow{2}{*}{$0,000^{*}$} \\
\hline & Lisans & 239 & 222,82 & 53255,00 & & \\
\hline \multirow{2}{*}{$\begin{array}{l}\text { Ücret ve Ek } \\
\text { Ödemeler }\end{array}$} & Önlisans & 154 & 153,80 & 23685,00 & \multirow{2}{*}{11750,000} & \multirow{2}{*}{$0,000^{*}$} \\
\hline & Lisans & 239 & 224,84 & 53736,00 & & \\
\hline \multirow{2}{*}{ Motivasyon } & Önlisans & 154 & 166,00 & 25564,50 & \multirow{2}{*}{13629,500} & \multirow{2}{*}{$0,000^{*}$} \\
\hline & Lisans & 239 & 216,97 & 51856,50 & & \\
\hline \multirow{2}{*}{ Özel Hayat } & Önlisans & 154 & 212,76 & 32764,50 & \multirow{2}{*}{15976,500} & \multirow{2}{*}{$0,025^{*}$} \\
\hline & Lisans & 239 & 186,85 & 44656,50 & & \\
\hline
\end{tabular}

${ }^{*} p<0,05$

Öğrencilerin alacakları akademik derecelere (önlisans-lisans) göre turizme (çalışma koşulları, kişi-turizm uyumu, sosyal statü-terfi, yönetici ve iş arkadaşları, ücret ve ek ödemeler, motivasyon ve özel hayat) yönelik algılarının anlamlı bir farklılık gösterip göstermediğini belirleyebilmek için yapılan Mann-Whitney $U$ testi sonuçları Tablo 3'te görülmektedir. Test sonuçlarına göre, ön lisans ve lisans bölümü öğrencilerinin çalışma koşulları ( $u=14863,0 ; p<0,05)$, kişi-turizm uyumu ( $u=16233,0$; $\mathrm{p}<0,05)$, sosyal statü-terfi $(\mathrm{u}=12053,0 ; \mathrm{p}<0,05)$, yönetici ve iş arkadaşları $(\mathrm{u}=12231,0$; $p<0,05)$, ücret ve ek ödemeler $(u=11750,0 ; p<0,05)$, motivasyon $(u=13629,5 ; p<0,05)$ ve 
özel hayat ( $u=15976,5 ; p<0,05)$ boyutlarındaki görüşleri arasında anlamlı bir farklılık olduğu saptanmıştır. Sıralama değeri ortalaması incelendiğinde, çalışma koşulları, kişiturizm uyumu, sosyal statü-terfi, yönetici ve iş arkadaşları, ücret ve ek ödemeler ve motivasyon boyutlarında ön lisans bölümü öğrencilerinin lisans bölümü öğrencilerine göre daha olumlu olduğu söylenebilir. Bununla birlikte araştırmada özel hayata yönelik olarak lisans bölümü öğrencilerinin ön lisans bölümü öğrencilerinden daha olumlu olduğu belirlenmiştir. Duman ve arkadaşlarının (2006) çalışmasında da turizm lisans, önlisans ve lise öğrencileri arasında sektör ve iş şartlarını değerlendirmeleri açısından farklılıklar bulunmuştur. Lisans ve lise öğrencileri önlisans öğrencilerine göre daha fazla endüstri uyumu göstermekte ve terfi imkanlarını daha olumlu değerlendirmekte, lisans ve lise öğrencileri önlisans öğrencilerine göre daha fazla sektörde kariyer yapmak istemekte Benzer bir durum yönetim ve iş arkadaşları konusunda da ortaya çıkmakta, önlisans öğrencileri sektör çalışanları ile uyum ve işbirliği konusunda zorlandıklarını belirtmektedirler. Sosyal statü açısından ise, lisans öğrencileri önlisans ve lise öğrencilerine göre daha olumlu düşünmektedirler.

Tablo 4. Öğrencilerin Sektör Deneyimlerine Göre Turizme Yönelik Algılarının Karşılaştırılması (Mann-Whitney U Testi)

\begin{tabular}{|c|c|c|c|c|c|c|}
\hline Boyutlar & $\begin{array}{c}\text { Sektör } \\
\text { Deneyimi }\end{array}$ & $\mathbf{N}$ & $\begin{array}{c}\text { Siralama } \\
\text { Değeri } \\
\text { Ortalaması }\end{array}$ & $\begin{array}{c}\text { S1ralama } \\
\text { Değerleri } \\
\text { Toplamı }\end{array}$ & $\begin{array}{c}\text { Mann- } \\
\text { Whitney U }\end{array}$ & $\mathbf{P}$ \\
\hline \multirow{2}{*}{$\begin{array}{l}\text { Çalışma } \\
\text { Koşulları }\end{array}$} & Evet & 162 & 216,63 & 35094,00 & \multirow{2}{*}{15531,000} & \multirow{2}{*}{$0,004^{*}$} \\
\hline & Hayır & 231 & 183,23 & 42327,00 & & \\
\hline \multirow{2}{*}{$\begin{array}{c}\text { Kişi-Turizm } \\
\text { Uyumu }\end{array}$} & Evet & 162 & 207,22 & 33569,00 & \multirow{2}{*}{17056,000} & \multirow{2}{*}{0,134} \\
\hline & Hayır & 231 & 189,84 & 43852,00 & & \\
\hline \multirow{2}{*}{$\begin{array}{c}\text { Sosyal Statü- } \\
\text { Terfi }\end{array}$} & Evet & 162 & 205,52 & 33295,00 & \multirow{2}{*}{17330,000} & \multirow{2}{*}{0,212} \\
\hline & Hayır & 231 & 191,02 & 44126,00 & & \\
\hline \multirow{2}{*}{$\begin{array}{l}\text { Yönetici ve İşs } \\
\text { Arkadaşları }\end{array}$} & Evet & 162 & 207,54 & 33621,50 & \multirow{2}{*}{17003,500} & \multirow{2}{*}{0,123} \\
\hline & Hayır & 231 & 189,61 & 43799,50 & & \\
\hline \multirow{2}{*}{$\begin{array}{l}\text { Ücret ve Ek } \\
\text { Ödemeler }\end{array}$} & Evet & 162 & 200,12 & 32420,00 & \multirow{2}{*}{18205,000} & \multirow{2}{*}{0,647} \\
\hline & Hayır & 231 & 194,81 & 45001,00 & & \\
\hline \multirow{2}{*}{ Motivasyon } & Evet & 162 & 206,42 & 33440,00 & \multirow{2}{*}{17185,000} & \multirow{2}{*}{0,165} \\
\hline & Hayır & 231 & 190,39 & 43981,00 & & \\
\hline \multirow{2}{*}{ Özel Hayat } & Evet & 162 & 207,52 & 33617,50 & \multirow{2}{*}{17007,500} & \multirow{2}{*}{0,120} \\
\hline & Hayır & 231 & 189,63 & 43803,50 & & \\
\hline
\end{tabular}

${ }^{*} p<0,05$

Öğrencilerin sektör deneyimi olup olmamasına (staj, okul dışı çalışma v.b.) göre turizme (çalışma koşulları, kişi-turizm uyumu, sosyal statü-terfi, yönetici ve iş arkadaşları, ücret ve ek ödemeler, motivasyon ve özel hayat) yönelik algılarının anlamlı bir farklılık gösterip göstermediğini belirleyebilmek amacıyla yapılan MannWhitney U testi sonuçları Tablo 4'te görülmektedir. Test sonuçlarına göre, öğrencilerin sektör deneyimi olup olmamasına göre turizmin çalışma koşullarına ( $u=15531,0$; $\mathrm{p}<0,05)$ ilişkin algıları arasında anlamlı bir farklılık tespit edilmiştir. Çalışma koşulları boyutuna ilişkin sıralama değeri ortalamasına göre, turizm sektöründe çalışmış olan 
öğrencilerin sektördeki çalışma koşulları ile ilgili olarak daha olumlu düşündükleri görülmektedir. Ancak kişi-turizm uyumu ( $\mathrm{u}=17056,0 ; \mathrm{p}>0,05)$, sosyal statü-terfi $(\mathrm{u}=17330,0 ; \mathrm{p}>0,05)$, yönetici ve iş arkadaşları $(\mathrm{u}=17003,5 ; \mathrm{p}>0,05)$, ücret ve ek ödemeler $(\mathrm{u}=18205,0 ; \mathrm{p}>0,05)$, motivasyon $(\mathrm{u}=17185,0 ; \mathrm{p}>0,05)$ ve özel hayat $(\mathrm{u}=17007,5 ; \mathrm{p}>0,05)$ boyutlarında öğrencilerin görüşleri arasında anlamlı bir farklılık bulunamamıştır. Sıralama değeri ortalamaları incelendiğinde, söz konusu boyutlara yönelik algının aynı sevilerde olduğu söylenebilir.

Tablo 5. Öğrencilerin Ailesinde Turizm Çalışanı Olup Olmamasına Göre Turizme Yönelik Algılarının Karşılaştırılması (Mann-Whitney U Testi)

\begin{tabular}{|c|c|c|c|c|c|c|}
\hline Boyutlar & $\begin{array}{c}\text { Ailede } \\
\text { Sektörde } \\
\text { Çalışan } \\
\end{array}$ & $\mathbf{N}$ & $\begin{array}{c}\text { Sıralama } \\
\text { Değeri } \\
\text { Ortalaması } \\
\end{array}$ & $\begin{array}{c}\text { Siralama } \\
\text { Değerleri } \\
\text { Toplamı }\end{array}$ & $\begin{array}{c}\text { Mann- } \\
\text { Whitney U }\end{array}$ & $\mathbf{P}$ \\
\hline \multirow{2}{*}{$\begin{array}{l}\text { Çalışma } \\
\text { Koşulları }\end{array}$} & Evet & 104 & 195,81 & 20364,00 & \multirow{2}{*}{14904,000} & \multirow{2}{*}{0,900} \\
\hline & Hayır & 289 & 197,43 & 57057,00 & & \\
\hline \multirow{2}{*}{$\begin{array}{l}\text { Kişi-Turizm } \\
\text { Uyumu }\end{array}$} & Evet & 104 & 182,43 & 18973,00 & \multirow{2}{*}{13513,000} & \multirow{2}{*}{0,126} \\
\hline & Hayır & 289 & 202,24 & 58448,00 & & \\
\hline \multirow{2}{*}{$\begin{array}{c}\text { Sosyal Statü- } \\
\text { Terfi } \\
\end{array}$} & Evet & 104 & 192,44 & 20014,00 & \multirow{2}{*}{14554,000} & \multirow{2}{*}{0,633} \\
\hline & Hayır & 289 & 198,64 & 57407,00 & & \\
\hline \multirow{2}{*}{$\begin{array}{c}\text { Yönetici ve İş } \\
\text { Arkadaşları }\end{array}$} & Evet & 104 & 196,28 & 20413,00 & \multirow{2}{*}{14953,000} & \multirow{2}{*}{0,940} \\
\hline & Hayır & 289 & 197,26 & 57008,00 & & \\
\hline \multirow{2}{*}{$\begin{array}{l}\text { Ücret ve Ek } \\
\text { Ödemeler }\end{array}$} & Evet & 104 & 194,10 & 20186,50 & \multirow{2}{*}{14726,500} & \multirow{2}{*}{0,761} \\
\hline & Hayır & 289 & 198,04 & 57234,50 & & \\
\hline \multirow{2}{*}{ Motivasyon } & Evet & 104 & 203,31 & 21144,00 & \multirow{2}{*}{14372,000} & \multirow{2}{*}{0,505} \\
\hline & Hayır & 289 & 194,73 & 56277,00 & & \\
\hline \multirow{2}{*}{ Özel Hayat } & Evet & 104 & 191,75 & 19942,00 & \multirow{2}{*}{14482,000} & \multirow{2}{*}{0,578} \\
\hline & Hayır & 289 & 198,89 & 57479,00 & & \\
\hline
\end{tabular}

${ }^{*} p<0,05$

Öğrencilerin sektörde çalışan yakınlarının olup olmamasına göre turizme (çalışma koşulları, kişi-turizm uyumu, sosyal statü-terfi, yönetici ve iş arkadaşları, ücret ve ek ödemeler, motivasyon ve özel hayat) yönelik algılarının anlamlı bir farklılık gösterip göstermediğini belirleyebilmek için yapılan Mann-Whitney U testi sonuçları Tablo 5'te görülmektedir. Sektörde çalışan yakını olanlar ile yakını olmayanların turizmin çalışma koşulları ( $u=14904,0 ; p>0,05)$, kişi-turizm uyumu ( $u=13513,0 ; p>0,05)$, sosyal statü-terfi $(u=14554,0 ; p>0,05)$, yönetici ve iş arkadaşları $(u=14953,5 ; p>0,05)$, ücret ve ek ödemeler ( $u=14726,5 ; p>0,05)$, motivasyon $(u=14372,0 ; p>0,05)$ ve özel hayat $(u=14482,0 ; \quad p>0,05)$ boyutlarındaki görüşleri arasında anlamlı bir farklılık bulunamamıştır. Sıralama değeri ortalaması incelendiğinde, tüm boyutlarda turizmde çalışan yakını olan öğrenciler ile yakını olmayan öğrencilerin turizme yönelik algılarının aynı düzeyde olduğu söylenebilir. 
Tablo 6. Öğrencilerin Turizm Alanını Seçmelerine Etki Eden Faktörlere Göre Turizme Yönelik Düşüncelerinin Karşılaştırılması (Kruskal-Wallis H Testi)

\begin{tabular}{|c|c|c|c|c|c|}
\hline Boyutlar & Turizm Seçimi & $\mathbf{N}$ & M.R. & Chi-Square & $\mathbf{P}$ \\
\hline \multirow{5}{*}{$\begin{array}{l}\text { Çalışma } \\
\text { Koşulları }\end{array}$} & Kendi Seçimim & 207 & 180,45 & \multirow{5}{*}{11,563} & \multirow{5}{*}{$0,021^{*}$} \\
\hline & Ailem & 46 & 208,15 & & \\
\hline & Arkadaşlarım & 52 & 213,48 & & \\
\hline & Rehber Öğretmen & 39 & 238,81 & & \\
\hline & Yatay Geçiş Hakkı & 49 & 205,68 & & \\
\hline \multirow{5}{*}{$\begin{array}{c}\text { Kişi-Turizm } \\
\text { Uyumu }\end{array}$} & Kendi Seçimim & 207 & 198,12 & \multirow{5}{*}{5,246} & \multirow{5}{*}{0,263} \\
\hline & Ailem & 46 & 167,20 & & \\
\hline & Arkadaşlarım & 52 & 215,23 & & \\
\hline & Rehber Öğretmen & 39 & 188,21 & & \\
\hline & Yatay Geçiş Hakkı & 49 & 207,90 & & \\
\hline \multirow{5}{*}{$\begin{array}{c}\text { Sosyal Statü- } \\
\text { Terfi }\end{array}$} & Kendi Seçimim & 207 & 191,24 & \multirow{5}{*}{4,482} & \multirow{5}{*}{0,345} \\
\hline & Ailem & 46 & 196,39 & & \\
\hline & Arkadaşlarım & 52 & 193,76 & & \\
\hline & Rehber Öğretmen & 39 & 192,71 & & \\
\hline & Yatay Geçiş Hakk1 & 49 & 228,77 & & \\
\hline \multirow{5}{*}{$\begin{array}{l}\text { Yönetici ve İş̧ } \\
\text { Arkadaşları }\end{array}$} & Kendi Seçimim & 207 & 190,40 & \multirow{5}{*}{3,328} & \multirow{5}{*}{0,505} \\
\hline & Ailem & 46 & 186,55 & & \\
\hline & Arkadaşlarım & 52 & 203,85 & & \\
\hline & Rehber Öğretmen & 39 & 210,14 & & \\
\hline & Yatay Geçiş Hakkı & 49 & 216,96 & & \\
\hline \multirow{5}{*}{$\begin{array}{l}\text { Ücret ve Ek } \\
\text { Ödemeler }\end{array}$} & Kendi Seçimim & 207 & 191,34 & \multirow{5}{*}{1,603} & \multirow{5}{*}{0,808} \\
\hline & Ailem & 46 & 194,28 & & \\
\hline & Arkadaşlarım & 52 & 206,33 & & \\
\hline & Rehber Öğretmen & 39 & 201,44 & & \\
\hline & Yatay Geçiş Hakkı & 49 & 210,02 & & \\
\hline \multirow{5}{*}{ Motivasyon } & Kendi Seçimim & 207 & 191,42 & \multirow{5}{*}{1,831} & \multirow{5}{*}{0,767} \\
\hline & Ailem & 46 & 195,16 & & \\
\hline & Arkadaşlarım & 52 & 212,26 & & \\
\hline & Rehber Öğretmen & 39 & 196,40 & & \\
\hline & Yatay Geçiş Hakkı & 49 & 206,59 & & \\
\hline \multirow{5}{*}{ Özel Hayat } & Kendi Seçimim & 207 & 184,00 & \multirow{5}{*}{6,149} & \multirow{5}{*}{0,188} \\
\hline & Ailem & 46 & 204,87 & & \\
\hline & Arkadaşlarım & 52 & 216,43 & & \\
\hline & Rehber Öğretmen & 39 & 210,21 & & \\
\hline & Yatay Geçiş Hakkı & 49 & 213,39 & & \\
\hline
\end{tabular}

${ }^{*} p<0,05$

Tablo 6'ya göre, öğrencilerin turizm bölümünü seçmelerine etki eden faktörler itibariyle turizme yönelik algıları değerlendirildiğinde, yalnızca turizmin çalışma koşulları boyutunda anlamlı bir farklılık olduğu görülmektedir $\left(X^{2}=11,563 ; p<0,05\right)$. Yapılan analiz, turizm bölümünü kendi seçimleri doğrultusunda tercih edenlerin en 
olumsuz; rehber öğretmelerin teşviki ile seçenlerin ise en olumlu görüşe sahip olduklarını göstermektedir.

\section{SONUÇ VE ÖNERILLER}

Turizm sektörü dünya çapında en hızlı gelişen ve büyüyen sektörlerin başında yer almaktadır. Dolayısıyla turizm faaliyetlerinin sürdürülebilir olabilmesi, sektördeki diğer paydaşlar kadar turizm eğitimi alan öğrencilerin turizme katılımıyla da mümkün olabilmektedir. $\mathrm{Bu}$ sebeple turizm eğitimi alan öğrencilerin genel olarak turizme yönelik görüşlerinin belirlenmesi büyük önem taşımaktadır. Bu kapsamda Karabük Üniversitesi turizm bölümü öğrencilerinin turizme yönelik algıları çalışma koşulları, kişi-turizm uyumu, sosyal statü-terfi, yönetici ve iş arkadaşları, ücret ve ek ödemeler, motivasyon ve özel hayat boyutlarına göre incelenmeye çalışılmıştır.

Elde edilen bulgular öğrencilerin en olumsuz algılarının sektördeki çalışma koşullarına yönelik olduğunu göstermektedir. Turizm endüstrisinde çalışma saatlerinin düzensiz, çok uzun, işin yorucu ve çalışma ortamının stresli olması, sektörün mevsimlik özelliği nedeniyle sektörde daimi bir iş bulmanın, sektörde çalışarak aile yaşantısını sürdürmenin zorluğu öğrencilerin sektöre karşı olumsuz bir tavır göstermelerinin temel sebepleridir. Bununla birlikte öğrenciler kişiliklerinin sektörde çalışmaya uygun (kişi-sektör uyumu) olduğuna inanmaktadırlar. Öğrencilerin, turizm sektöründeki işlerde bilgi ve becerilerini kullanabilecekleri, kişilik yapılarını turizmle uyumlu gördükleri, tempolu iş ortamını sevdikleri, insanlara hizmet ederek mutlu oldukları ve kısa sürede sektörde iyi noktalara geleceklerini düşündükleri söylenebilir.

Öğrenciler özel hayatlarına ve hafta sonu tatillerine önem vermektedirler. Ancak sektördeki düzensiz çalışma saatleri kişilerin özel hayatını olumsuz etkileyecektir.

Öğrenciler yaptıkları işi eğlenceli bulmaktadırlar. Sektörün sunduğu farklı ortamlar, farklı ülke ve kültürlerden gelen insanlarla tanışma imkanı sunması, tatil beldelerindeki gece hayatı ve eğlenceli yaşam sektörü cazip kılmaktadır. Bununla birlikte öğrenciler sektörün toplumda saygın bir meslek olarak algılanmadığına "garsonluk" işi olarak algılandığına inanmaktadırlar.

Öğrenciler sektörden elde edilen kazançların rahat bir yaşam sürmek için yetersiz olduğuna inanmaktadırlar. Bu durum sektörde ödenen ücret ve elde edilen yan gelirlerin yetersiz olduğunu göstermektedir.

Öğrenciler, sektörde terfi imkanları ile ilgili olarak da olumsuz algılara sahiptirler. Nitekim öğrenciler sektörde terfi imkanının kıstlı olduğuna, kişilerin terfi etmesinin torpile bağlı olduğuna inanmaktadırlar. Bununla birlikte çalışanlar terfi ettirilirken tecrübelerinin dikkate alındığını yani liyakate göre terfi ettirildiğini düşünmektedirler.

Çalışmada öğrencilerin turizme yönelik algılarındaki farklılık çeşitli değişkenlere göre incelenmiş olup kadın ve erkeklerin turizme yönelik düşünceleri arasında anlamlı bir farklılık bulunamamıştır. Bununla birlikte öğrencilerin eğitim 
gördüğü önlisans ve lisans bölümlerine göre turizme yönelik algılarında anlamlı bir farklılık saptanmıştır. Çalışma koşulları, kişi-turizm uyumu, sosyal statü-terfi, yönetici ve iş arkadaşları, ücret ve ek ödemeler ve motivasyon boyutlarında önlisans öğrencilerinin algıları lisans öğrencilerine göre daha olumludur. Ancak özel hayata yönelik olarak lisans öğrencilerinin önlisans öğrencilerinden daha olumlu olduğu ortaya çıkmıştır.

Öğrencilerin sektör deneyimlerine göre turizme yönelik algılarının kişi-turizm uyumu, sosyal statü-terfi, yönetici ve iş arkadaşları, ücret ve ek ödemeler, motivasyon ve özel hayat boyutlarında anlamlı bir farklılık göstermediği tespit edilmiştir. Ancak sektör deneyimi bazında turizmin çalışma koşullarına ilişkin düşünceleri arasında anlamlı bir farklılık tespit edilmiştir. Sonuçlar, turizm sektöründe çalışmış/staj yapmış olan öğrencilerin sektördeki çalışma koşulları ile ilgili olarak daha olumlu düşündüklerini ortaya koymaktadır. Staj öğrencilerin üniversite ortamından çalışma ortamına geçiş sürecinde önemli bir dönüm noktasıdır. Staj sürecinde öğrenci sektörün çalışma koşullarını tanımakta, sektöre uyum sağlayıp sağlayamayacağını, kariyer ve gelişme olanaklarını inceleyerek sektörde devam edip etmeyeceğine karar vermekte ve geleceğini şekillendirmektedir. Ancak staj yapan öğrencilerin sektörde ucuz işgücü olarak algılanması ve görevi dışında işlerin yaptırılması öğrencilerin sektöre karşı olumsuz tutum takınmalarına neden olmaktadır.

Öğrencilerin sektörde çalışan yakınlarının olup olmadığı bağlamında turizme ilişkin görüşleri arasında anlamlı bir farklılık bulunamamıştır. Öğrencilerin turizm bölümünü seçmelerine neden olan faktörler itibariyle turizme yönelik düşüncelerinin, yalnızca turizmin çalışma koşulları boyutunda anlamlı bir farklılık gösterdiği tespit edilmiştir. Bu boyutla ilgili olarak en olumsuz görüşler, turizm bölümünü kendi seçimleri doğrultusunda tercih edenlerde belirlenirken, rehber öğretmeleri aracılığıyla bu bölümü seçenlerin en olumlu görüşe sahip olduğu bulunmuştur. Bu çalışmadan elde edilen bulgular öğrencilerin yarısının turizm eğitimi almayı isteyerek tercih ettiğini göstermektedir.

Turizm bölümünde eğitim gören öğrencilerin sektöre karşı tutumlarını ve kariyer beklentilerini anlamak, sektörün ihtiyacı olan kalifiye iş gücünün yetiştirilmesi açısından önem taşımaktadır. Böylece durumun ortaya konması, hem eğitim kurumları hem ilgili resmi kurumlar (Kültür ve Turizm Bakanlığı gibi) hem de sektör tarafından yapılan hataların önlenmesi, eğitimli işgücünün sektörden uzaklaşmasının önüne geçilmesi açılarından yol gösterici olacaktır. Bu bağlamda devlet kurumlarının doğru işgücü politikaları oluşturmaları, eğitim kurumlarının eğitim kurumu-sektör dengesini kurarak sektörün ihtiyaç duyduğu nitelikte turizm elemanı yetiştirmek yönünde çaba göstermeleri, turizm işletmelerinin ise kurumsallaşarak ve profesyonel bir yönetim anlayışı benimseyerek turizm eğitimi alan öğrencilerin sektörden uzaklaşmalarını engelleyecek adımları atmaları gerekmektedir. Ayrıca yapılacak yasal düzenlemelerle çalışanların haklarının korunması öğrencilerin sektörden uzaklaşmalarının engelleyecektir. 


\section{KAYNAKÇA}

Ağaoğlu , O., K.. (1991). Türkiye'de Turizm Eğitimi ve Etkinliği, Milli Prodüktivite Merkezi Yayınları 439, Ankara: Yeniçă̆ Bası Yayın San. Ltd. Şti.

Aksu, A., A., Köksal, C., D. (2005). "Perceptions and attitudes of tourism students in Turkey", International Journal of Contemporary Hospitality Management, 17 (4/5), 436-447.

Altman, L.A., ve Brother, L.R. (1995). Career Longevity of Hospitality Graduates, FIU Review, 13 (2): 77-83.

Aymankuy, Y. ve Aymankuy, Ş. (2013). Turizm İşletmeciliği Eğitimi Alan Öğrencilerin Turizm Sektöründeki İstihdamla İlgili Görüşleri ve Sektördeki Kariyer Beklentileri (Balıkesir Üniversitesi Turizm İşletmeciliği Ve Otelcilik Yüksekokulu Örneği), Akademik Bakış Dergisi, 35, 1-21.

Baltacı, F. ve Üngören, E. (2010). Turizm Eğitimi Alan Öğrencilerin Eğitim Memnuniyetlerinin ve Geleceğe Yönelik Bakış Açlarının Belirlemesine Yönelik Bir Araştırma, 11. Ulusal Turizm Kongresi, 312-324.

Birdir, K. (2002). Turizm ve Otel işletmeciliği Eğitimi Alan Lisans Öğrencilerinin Turizm Endüstrisinde Çalışmayı Tercih Etmemelerinin Temel Nedenleri: Bir Nominal Grup Tekniği Araştırması, Turizm Ĕ̆itimi Konferans - Workshop, Turizm Bakanlığı Turizm Eğitimi Genel Müdürlüğü, Ankara: 495-504.

Boella, M. J. (2000). Human Resource Management in the Hospitality Industry. (7th ed). Cheltenham: Stanley Thornes.

Boylu, Y. Ve Arslan E. (2014). Türkiye'deki Turizm Eğitiminin Rakamsal Gelişmeler Açısından Değerlendirilmesi. Gazi Üniversitesi Turizm Fakültesi Dergisi, 1: 79-97.

Chen, J. S., Kay Hei-Lin Chu, Wu-Chung Wu. (2000) "Tourism students' perceptions of work values: a case of Taiwanese universities", International Journal of Contemporary Hospitality Management, Vol. 12 Iss: 6, pp.360 - 365.

Chuang, N. K., ve Dellmann-Jenkins, M. (2010). Career decision making and intention: A study of hospitality undergraduate students, Journal of Hospitality and Tourism Research, 34(4), 512-530.

Çavuş, Ş. ve Kaya, A. (2015). Turizm Lisans Eğitimi Alan Öğrencilerin Kariyer Planları Ve Turizm Sektörüne Yönelik Tutumu, Manas Sosyal Araştırmalar Dergisi, 4, (5), 101-117.

Dinçer, F. İ., Akova, O. ve Kaya, F. (2013). Meslek Yüksekokulu Turizm ve Otel İşletmeciliği Programı Öğrencilerinin Kariyer Planlamasi Üzerine Bir Araştırma: Istanbul Üniversitesi ve Gümüşhane Üniversitesi Örneği, Electronic Journal of Occupational Improvement and Reserach, 1 (2), 42- 56

Duman. T., Tepeci, M. ve Unur, K. (2006). Mersin'de Yükseköğretim ve Orta Öğretim Düzeyinde Turizm Eğitimi Almakta Olan Öğrencilerin Sektörün Çalışma Koşullarını Algılamaları ve Sektörde Çalışma İsteklerinin Karşılaştırmalı Analizi, Anatolia: Turizm Araştırmaları Dergisi, 17(1), 51-69.

Erdinç, S. B. (2012). Determeninig of College Students' Trends about Tourism Sector: A Case Study at Akdeniz Universty . Procedia Social and Behavioral Sciences , 1573-1577.

Gharamaleki, Mohammad Reza Eivazi (2011). “Lisans Düzeyinde Turizm Eğitimi Alan Öğrencilerin Turizm Eğitimi Veren Kurumları Değerlendirmeleri; İran Türkiye 
Karşılaştırması", Gazi Üniversitesi Eğitim Bilimleri Enstitüsü Turizm İşletmeciliği Eğitimi Anabilim Dalı Doktora Tezi, Ankara.

Güzel, T., Akdağ, G., Güler, O. ve Şener, S. (2014). Turizm Eğitimi Alan Öğrencilerin Turizmde Kariyer Algılamaları: Çanakkale, Mersin ve Kıbrıs'ta Bir Araştırma,18 Nisan 2014, 3.Doğu Akdeniz Sempozyumu, ss:176-183, Mersin.

Hacıoğlu, N. (1985). Turizm Eğitimi Yeterli mi?, Milliyet Gazetesi,s.8.

Hacıoğlu, N. (2010). Turizm Pazarlaması, 7.Baskı, Ankara: Nobel Yayınevi.

Halıcı, A. ve Delil Y. (2003). Büro yönetimi öğrencilerinin mesleki algılamalarına yönelik bir uygulama. Gazi Üniversitesi Ticaret ve Turizm Eğitim Fakültesi Dergisi, (1), 22-37.

Jiang, B. ve Tribe, J. (2009). 'Tourism jobs - short lived professions': Student attitudes towards tourism careers in China, Journal of Hospitality, Leisure, Sport \& Tourism Education, 8 (1), 4-19.

Kalaycı, Ş. (2010). SPSS Uygulamalı Çok Değişkenli İstatistik Teknikleri, 5. Baskı, Ankara: Asil Yayın Dağıtım.

Kayış, A. (2009). Güvenirlik Analizi. Şeref Kalaycı (Editör), SPSS Uygulamalı Çok Değişkenli İstatistik Teknikleri. Ankara: Asil Yayın Dağıtım.

Kozak, M. A. ve Kızılırmak, İ. (2001). Türkiye'de Meslek Yüksekokulu Turizm-Otelcilik Programı Öğrencilerinin Turizm Sektörüne Yönelik Tutumlarının Demografik Değişkenlere Göre Değişimi:Anadolu, Akdeniz ve Karadeniz Teknik Üniversitesi Öğrencileri Üzerine Bir Uygulama, Anatolia:Turizm Araştırmaları Dergisi, 12(1), 9-16.

Krejcie, R. V. ve Morgan, D. W. (1970) "Determining Sample Size for Research Activities", Educational and Psychological Measurement, 30, 607-610.

Kuşluvan, S. ve Kuşluvan, Z. (2003) "Perceptions and attitudes of undergraduate tourism students towards working in the tourism industry in Turkey", Tourism Management, 21, 251-269.

Kuşluvan, S. ve Kuşluvan, Z. (2003) "Perceptions and Attitudes of Undergraduate Tourism Students Towards Working in the Tourism and Hospitality Industry in a Developing Economy", S. Kuşluvan (Ed.) Managing Employee Attitudes and Behaviors in the Tourism and Hospitality Industry. 77-98, New York: Nova Science Publishers Inc.

Lee, C. ve Kang, S. (1998). Measuring Earnings Inequality and Median Earning in the Tourism Industry, Tourism Management, 19(4): 341-348.

Lu, T., ve Adler, H. (2009). Career goals and expectations of hospitality and tourism students in China, Journal of Teaching in Travel \& Tourism, 9(1-2), 63-80.

Orhan, A. (2015). Türkiye'de Lisans Düzeyinde Turizm Eğitimi Alan Öğrencilerin Turizm Sektörü Ile Ilgili Algilarinin Çalişma Niyetleri Üzerindeki Etkisinin Belirlenmesi, Eskişehir Osmangazi Üniversitesi Sosyal Bilimler Enstitüsü Turizm İşletmeciliği Anabilim Dalı Yayımlanmamış Yüksek Lisans Tezi Eskişehir.

Öztürk, Y. ve Pelit, E. (2008). Turizm Alanında İşletmecilik ve Öğretmenlik Eğitimi Alan Öğrencilerin Kariyer Tercihleri Üzerine Bir Araştırma, III. Balıkesir Ulusal Turizm Kongresi, Balıkesir: 353-360. 
Pavesik, D.V. ve Breymer, R.A. (1990). Job Satisfaction: What is Happening to the Young Managers, Cornell Hotel and Restaurant Administration Quarterly, 31 (1): 90-96.

Pizam, A. Ve Telismen-Kosuta, N. (1989). Tourism as a Factor of Change: Results and Analysis. J. Bystrzanowski (Ed.). Tourism as Factor of Change: A Sociological Study, 69-93, Vienna:Central Library of the Slovak Academy of Sciences.

Richardson, S., ve Butler, G. (2012). Attitudes of Malaysian tourism and hospitality students' towards a career in the industry, Asia Pacific Journal of Tourism Research, 17(3), 262-276.

Riegel, C. ve Dallas, M. (1998) Hospitality and Tourism Careers: A Blue Print for Success. Prentice Hall Inc.: New Jersey.

Roney, S. A., ve Öztin, P. (2007). Career perceptions of undergraduate tourism students: A case study in Turkey, Journal of Hospitality, Leisure, Sport and Tourism Education, 6(1), 4-17.

Ross, G. F. (1994). What do Australian School Leavers Want of Industry? Tourism Management, 15 (1): 62-66.

Savickas, M. L. (1990). The use of career choice measures in counseling practice. Testing in Counseling Practice, 373-417.

Unur, K., Duman, T. ve Tepeci, M. (2004) Lisans Düzeyindeki Turizm Eğitimi Alan Öğrenciler Sektörde Kariyer Yapmaya Nasıl Bakıyor?, I. Ulusal Turizm Kongresi, Balıkesir: 390414. 